\title{
Sensorimotor Gating Deficits in Transgenic Mice Expressing a Constitutively Active Form of $\mathrm{G}_{\mathrm{s}} \alpha$
}

\author{
Thomas J Gould, 1,4, Scott P Bizily ${ }^{2,3,4}$, Jan Tokarczyk ${ }^{3}$, Michele P Kelly ${ }^{2,3}$, Steven J Siegel ${ }^{3}$, Stephen J Kanes ${ }^{3}$ \\ and Ted Abel*,2 \\ 'Department of Psychology, Temple University, Weiss Hall, Philadelphia, PA, USA; '2Department of Biology, University of Pennsylvania, \\ Philadelphia, PA, USA; ${ }^{3}$ Division of Neuropsychiatry, University of Pennsylvania, Philadelphia, PA, USA
}

\begin{abstract}
Schizophrenia is a complex disorder characterized by wide-ranging cognitive impairments, including deficits in learning as well as sensory gating. The causes of schizophrenia are unknown, but alterations in intracellular G-protein signaling pathways are among the molecular changes documented in patients with schizophrenia. Using the CaMKIl $\alpha$ promoter to drive expression in neurons within the forebrain, we have developed transgenic mice that express a constitutively active form of $G_{s} \alpha\left(G_{s} \alpha^{*}\right)$, the $G$ protein that couples receptors such as the $D_{1}$ and $D_{5}$ dopamine receptors to adenylyl cyclase. We have also generated mice in which the CaMKIl $\alpha$ promoter drives expression of a dominant-negative form of protein kinase $A, R(A B)$. Here, we examine startle responses and prepulse inhibition of the startle reflex (PPI) in these $G_{s} \alpha^{*}$ and $R(A B)$ transgenic mice. $G_{s} \alpha^{*}$ transgenic mice exhibited selective deficits in PPI, without exhibiting alterations in the startle response, whereas no deficit in startle or PPI was found in the R(AB) transgenic mice. Thus, overstimulation of the cAMP/PKA pathway disrupts PPI, but the CAMP/PKA pathway may not be essential for sensorimotor gating. $G_{s} \alpha^{*}$ transgenic mice may provide an animal model of certain endophenotypes of schizophrenia, because of the similarities between them and patients with schizophrenia in G-protein function, hippocampus-dependent learning, and sensorimotor gating.

Neuropsychopharmacology (2004) 29, 494-50I, advance online publication, 17 December 2003; doi: I 0.I 038/sj.npp. I 300309
\end{abstract}

Keywords: G proteins; protein kinase A; startle response; prepulse inhibition; schizophrenia; animal model

\section{INTRODUCTION}

Schizophrenia is a complex and chronic illness characterized by positive psychotic symptoms as well as negative symptoms such as social withdrawal, impaired social functioning, and cognitive dysfunction (Andreasen and Black, 1995). Population and familial studies demonstrate that schizophrenia has a strong genetic component that may depend on the presence and, possibly, interaction of alleles at several different loci (for reviews, see Bassett et al, 2000; Sawa and Snyder, 2002). Although it is not possible to model a phenotype as complex and distinctly human as schizophrenia in animals, it is feasible to identify measurable subphenotypes, or endophenotypes, characteristic of patients with schizophrenia that can be reproduced in genetically altered laboratory rodents (Bucan and Abel,

\footnotetext{
* Correspondence: Dr T Abel, Department of Biology, University of Pennsylvania, 319 Leidy Labs, 38th and Hamilton Walk, Philadelphia, PA 19104, USA, Tel: + I 215898 56/4, Fax: + I 215898 8780, E-mail: abele@sas.upenn.edu

${ }^{4}$ These authors contributed equally to this work.

Received 02 July 2003; revised 23 September 2003; accepted 06 November 2003

Online publication: 10 November 2003 at http://www.acnp.org/ citations/Npp I | I00303294/default.pdf
}

2002; Tarantino and Bucan, 2000). This approach is useful in identifying candidate genes that may contribute to schizophrenia.

One endophenotype that has been the focus of many studies is deficient sensorimotor gating, a reduction in the brain's ability to filter excessive sensory information and generate appropriate motor responses. Aberrant gating is commonly identified in tests of prepulse inhibition of startle (PPI) (reviewed in Koch, 1999). In these tests, a startle response produced by a strong unexpected stimulus is compared to a response produced by an identical stimulus preceded $\sim 50-150 \mathrm{~ms}$ by a lower intensity prestimulus. Normally, a decreased startle response is observed when the prestimulus precedes the startle stimulus. However, multiple neuropsychiatric disorders that are associated with a reduced ability to gate intrusive information are also associated with deficits in PPI (reviewed in Koch, 1999). For instance, schizophrenia patients and their first-degree relatives exhibit a smaller reduction in the startle response or, in other words, show reduced PPI (Cadenhead et al, 2000; Geyer and Braff, 1987; Swerdlow et al, 1994; Swerdlow and Geyer, 1998). In addition, investigators have also developed protocols to assess auditory gating directly in the brain by using surface electrodes or, in animals, intracranial electrodes, and have found similar results 
(Adler et al, 1982; Boutros et al, 1991; Clementz et al, 1997; Connolly et al, 2003; Erwin et al, 1991; Freedman et al, 1996; Judd et al, 1992; Stevens et al, 1996).

Schizophrenia has been proposed to result from changes in a variety of neurotransmitter systems including glutamate, dopamine, and serotonin (reviewed by Owen, 2000; Sawa and Snyder, 2002; Weickert and Kleinman, 1998). Studies in rodents have demonstrated that each of these systems has some role in regulating sensorimotor gating. In particular, dopamine and serotonin agonists and NMDA antagonists strongly disrupt PPI (reviewed in Geyer et al, 2001). Further dissection of the dopaminergic pathways that contribute to PPI by the use of selective dopamine receptor antagonists that have similar pharmacological actions as typical antipsychotic medications has provided additional support for a dopamine-based abnormality in schizophrenia. Specifically, dopaminergic signaling through the $D_{2}$ receptor but not $\mathrm{D}_{3}, \mathrm{D}_{4}$, or $\mathrm{D}_{5}$ receptors is thought to be involved in PPI (Peng et al, 1990; Ralph et al, 1999). Additionally, signaling through $\mathrm{D}_{1}$ receptors may potentiate the effect of $\mathrm{D}_{2}$ signaling (Peng et al, 1990; Wan et al, 1996) and, in mice, $\mathrm{D}_{1}$-family receptor agonists disrupt PPI (Holmes et al, 2001; Ralph-Williams et al, 2003). It is less clear exactly which serotonin receptors are involved in PPI. Agonist/antagonist studies suggest that the $5-\mathrm{HT}_{1 \mathrm{~A}}, 5-\mathrm{HT}_{1 \mathrm{~B}}$, and $5-\mathrm{HT}_{2 \mathrm{~A}}$ receptors may contribute (Dulawa et al, 1997, 1998; Rigdon and Weatherspoon, 1992; Sipes and Geyer, 1994, 1995a,b), although other members of the serotonin receptor family have yet to be investigated.

Aside from alterations to neurotransmitter receptors, mutations in signal transduction molecules downstream of these receptors could have strong effects on sensorimotor gating. One likely class of proteins in this category is the $\mathrm{G}$ proteins to which dopamine, serotonin, and glutamate receptors couple. Interestingly, changes to $G_{s}, G_{i}$, and $G_{o}$ have been observed in patients with schizophrenia. Specifically, the left hemisphere of patients with schizophrenia appears to have reduced $G_{i} \alpha, G_{o} \alpha$, and $G_{q} \alpha$ immunoreactivity (Nishino et al, 1993; Okada et al, 1991, 1994; Yang et al, 1998). In addition, mononuclear leukocytes isolated from untreated patients have elevated levels of $\mathrm{G}_{\mathrm{s}} \alpha$ that are not observed in patients receiving clozapine or haloperidol (Avissar et al, 2001).

$\mathrm{G}_{\mathrm{s}}$-coupled receptors stimulate the cAMP/PKA pathway. Activation of this signal transduction cascade may disrupt PPI by acting similarly to $D_{1} / D_{5}$ receptor agonists, which disrupt PPI (Holmes et al, 2001; Ralph-Williams et al, 2003). Alternatively, activation of the cAMP/PKA signaling pathway may enhance neural transmission, thus stimulating dopamine release in the nucleus accumbens. As an initial attempt to examine the role of $\mathrm{G}$ proteins and the cAMP/ PKA system in sensorimotor gating, we measured PPI in wild-type and transgenic mice that express a constitutively active form of $\mathrm{G}_{\mathrm{s}} \alpha\left(\mathrm{G}_{\mathrm{s}} \alpha^{*}\right)$ (Abel et al, 1997a; Wand et al, 2001) and transgenic mice that express a dominant-negative form of protein kinase A, R(AB) (Abel et al, 1997b). Both transgenes are under the control of the CaMKII $\alpha$ promoter that drives expression in neurons within forebrain areas including the neocortex, olfactory bulb, hippocampus, striatum, and amygdala (Mayford et al, 1996). These transgenic mice exhibited selective impairments in hippocampus-dependent forms of memory and alterations in hippocampal synaptic physiology (Abel et al, 1997a,b). If $\mathrm{G}_{\mathrm{s}} \alpha^{*}$ animals also have a disruption of PPI without any alteration in baseline startle, this would support a hypothesis that excessive stimulation of the cAMP/PKA pathway by elevated $G_{s}$ signaling (or possibly, in the context of schizophrenia, by reduced $G_{i}$ signaling) produces sensorimotor gating deficits and possibly other endophenotypes of schizophrenia. The examination of PPI and startle in the $\mathrm{R}(\mathrm{AB})$ transgenic mice allows us to determine if PKA in forebrain neurons is necessary for sensorimotor gating. Portions of this research have been presented in abstract form (Gould and Abel, 2000).

\section{MATERIAL AND METHODS}

\section{Genetically Modified Mice}

$\mathrm{G}_{\mathrm{s}} \alpha^{*}$ and $\mathrm{R}(\mathrm{AB})$ transgenic mice were maintained in breeding colonies at the University of Pennsylvania in a hemizygous state on a C57BL/6J background. Currently, the $\mathrm{G}_{\mathrm{s}} \alpha^{*}$ transgenic mouse colony is at N7-N11 on a C57BL/6J background and the $\mathrm{R}(\mathrm{AB})$ transgenic mouse colony is at N8-N10 on a C57BL/6J background. R(AB) carries mutations in both cAMP-binding sites and acts as a dominant inhibitor of both types of PKA catalytic subunits (Clegg et al, 1987; Ginty et al, 1991a,b; Mellon et al, 1989). R(AB) transgenic mice used in this study were from the $R(A B)-1$ line described in Abel et al (1997b), and the forebrainspecific CaMKII $\alpha$ promoter was used to drive the expression of this transgene. $G_{s} \alpha^{*}$ transgenic mice were from the $G_{s} \alpha^{*}$ 1 transgenic mouse line. In these $\mathrm{G}_{\mathrm{s}} \alpha^{*}$ transgenic mice, the CaMKII $\alpha$ promoter was used to drive expression of a constitutively active mutation, $\mathrm{G}_{\mathrm{s}} \alpha \mathrm{Q} 227 \mathrm{~L}$ (Abel et al, 1997a; Wand et al, 2001). In the Wand et al (2001) study, expression of the $G_{s} \alpha^{*}\left(G_{s} \alpha Q 227 L\right)$ was demonstrated in the hippocampus, cortex, striatum, and nucleus accumbens (see Figure 5, Wand et al, 2001). Consistent with our analysis of other transgenic lines, the CaMKII $\alpha$ promoter drove transgene expression sufficient to increase basal adenylyl cyclase activity 2-4-fold, depending on the brain region studied (see Table 4, Wand et al, 2001). For genotyping, tail DNA was prepared and analyzed by Southern blotting using a transgene-specific probe as described (Abel et al, 1997b). Mutants and wild-type littermate controls were tested in a balanced fashion in each experiment. In most cases, within a given litter, a transgenic mouse was selected for experiments only if it could be paired with a wild-type animal of the same sex. Animals used in PPI experiments were at least 8 weeks old and group housed with $a d l i b$ access to food and water. Both male and female wild-type and transgenic mice were used in the experiments. In a previous study, no significant effects of sex were observed (Gould and Abel, 2000).

\section{Startle Response and Prepulse Inhibition Tests}

Reflexive startle and PPI, the ability of a low-intensity stimulus to decrease startle response, were tested using the SR-Lab System (San Diego, CA) as described in Tarantino et al (2000). The system includes a $35 \times 33 \times 38.5 \mathrm{~cm}^{3}$ sound-attenuating chamber ventilated with a small fan and illuminated by a $15 \mathrm{~W}$ light bulb mounted in the ceiling. The 
chambers contained a stabilimeter that consists of a clear Plexiglas cylinder $\left(16 \times 8.75 \mathrm{~cm}^{2}\right)$ mounted to a Plexiglas frame $\left(12.5 \times 20.5 \times 0.6 \mathrm{~cm}^{3}\right)$. The cylinder and frame were elevated $2.75 \mathrm{~cm}$ above a $30 \mathrm{~cm} \times 30 \mathrm{~cm} \times 4 \mathrm{~cm}$ Plexiglas base by four screws stationed under each corner of the stabilimeter frame. Acoustic stimuli were delivered through $6 \mathrm{~cm}$ speakers mounted in the enclosure ceilings, $23 \mathrm{~cm}$ above the cylinders. Startle responses were transduced by the piezoelectric accelerometers mounted beneath the Plexiglas frames. Output signals were digitized, rectified, and recorded as consecutive $1 \mathrm{~ms}$ readings on an IBM 486 computer using San Diego Instruments Startle Reflex software. The average startle response and maximum amplitude of the startle response were recorded as San Diego Instruments startle units.

Mice were tested using two different startle/PPI protocols that were based on protocols successfully used to study PPI in prior studies (Tarantino et al, 2000; Ralph et al, 1999). These programs differed in the interstimulus interval, the duration of the sampling of the startle response, whether intertrial intervals varied, and the decibel levels at which prepulses were presented. Despite these differences, the two startle/PPI protocols yielded similar results. In each case, mice were acclimated for at least $30 \mathrm{~min}$ in the testing facility before beginning startle/PPI sessions. Percent PPI was calculated using the following formula: $\{100-$ (startle + prepulse/startle alone $) \times 100\}$. PPI was reported as percent inhibition of the average startle response. Errors reported represent the standard error of the mean. The maximum amplitude of the startle response within the collection window was also evaluated and was shown to correlate with the average startle response (Gould and Abel, 2000; Tarantino et al, 2000).

\section{Protocol 1}

This protocol is based on a PPI protocol used by Tarantino et al (2000). Each session started with $5 \mathrm{~min}$ of $65 \mathrm{~dB}$ background noise, followed by both startle and PPI trials. Startle trials consisted of $40 \mathrm{~ms}$ pulses at 90, 95, 100, 105, 110,115 , and $120 \mathrm{~dB}$. Each trial was presented five times in a randomized order with a 15-s intertrial interval. Startle trials were followed by PPI trials. For these trials, a $20 \mathrm{~ms}$ prepulse terminated $40 \mathrm{~ms}$ prior to the onset of a $40 \mathrm{~ms}$ $120 \mathrm{~dB}$ startle stimulus. PPI was recorded for prepulses of $73,78,82$, and $87 \mathrm{~dB}$. All prepulse trials were presented five times in a randomized order with a 15-s intertrial interval. Data were recorded as $1001 \mathrm{~ms}$ voltage readings, which were averaged over the collection interval to give an average startle measure for each trial.

\section{Protocol 2}

This protocol is based on a PPI protocol used by Ralph et al (1999). Each session started with a 5 min acclimation period with a $65 \mathrm{~dB}$ acoustic background noise followed by five $120 \mathrm{~dB}$ startle pulses, in an effort to make subsequent startle trials less variable. Startle trials consisted of $40 \mathrm{~ms}$ pulses at 0 (no stimulus), 90, 95, 100, 105, 110, 115, and $120 \mathrm{~dB}$. Each trial was presented five times in a randomized order with an intertrial interval randomized from 10 to $20 \mathrm{~s}$. Startle trials were followed by PPI trials.
Each prepulse was $20 \mathrm{~ms}$ in duration, followed by a $40 \mathrm{~ms}$ startle stimulus of $120 \mathrm{~dB}$. There was a $100 \mathrm{~ms}$ interstimulus interval between prepulse offset and startle stimulus onset. PPI was recorded for prepulse intensities of 69,73 , and $81 \mathrm{~dB}$, and no stimulus. Each prepulse trial was administered five times in a random order. Data were collected as 60 $1 \mathrm{~ms}$ voltage readings, which were averaged over the collection interval to give an average startle measure for each trial.

\section{Data Analysis}

SPSS (SPSS, version 11.5) was used for statistical analyses described in this paper. A repeated-measures analysis of variance was used to detect differences with a minimal significance level of $\alpha=0.05$. Stimulus level was the repeated measure and genotype was compared across subjects. Transgenic mice and the corresponding wildtype mice were compared. Tukey-adjusted post hoc comparisons were used to examine effects when interactions were found. For protocol 2, mice were tested in a nostimulus condition (No Stim) to test for differences in baseline levels of activity. These data were analyzed separately, comparing transgenic to matched wild-type mice using independent $t$-tests.

\section{RESULTS}

\section{$\mathrm{G}_{s} \alpha^{*}$ Transgenic Mice, but not $\mathrm{R}(\mathrm{AB})$ Transgenic Mice, Exhibit PPI Deficits (Protocol 1)}

Protocol 1 tested PPI with a $40 \mathrm{~ms}$ interstimulus interval between the $20 \mathrm{~ms}$ prepulse and the $40 \mathrm{~ms}$ startle stimulus. $\mathrm{G}_{\mathrm{s}} \alpha^{*}$ transgenic mice $(n=8)$ and wild-type littermate mice $(n=8)$ were tested for startle reactivity at seven different intensities and tested for PPI at four prepulse intensities, each paired with a $120 \mathrm{~dB}$ startle stimulus (Figure 1). The average $G_{s} \alpha^{*}$ startle response was not significantly different from wild-type mice $(\mathrm{F}(1,14)=0.66 ; p=0.81)$, nor was there a significant genotype $\times \mathrm{dB}$ interaction effect $(\mathrm{F}(6,84)=0.27 ; p=0.95$; Figure 1a). Startle response was significantly different across dB levels $(F(6,84)=23.96$; $p=0.001)$. Using this protocol, PPI was disrupted in $\mathrm{G}_{\mathrm{s}} \alpha^{\star}$ mice with a significant effect of genotype $(\mathrm{F}(1,14)=9.53$; $p<0.01)$, and PPI levels were significantly different across $\mathrm{dB}$ levels $(\mathrm{F}(3,42)=16.92 ; p<0.001)$, but no significant genotype $\times \mathrm{dB}$ interaction was found $(\mathrm{F}(3,42)=0.375$; $p=0.77$; Figure $1 \mathrm{~b})$.

$\mathrm{R}(\mathrm{AB})$ transgenic mice $(n=11)$ and wild-type littermate mice $(n=11)$ were also tested with protocol 1 (Figure 2 ). The average $\mathrm{R}(\mathrm{AB})$ startle response was not significantly different from wild-type mice $(\mathrm{F}(1,20)=1.63 ; p=0.22)$, nor was there a significant genotype $\times \mathrm{dB}$ interaction effect $(\mathrm{F}(6,120)=0.13 ; p=0.99$; Figure $2 \mathrm{a})$. Startle response was significantly different across $\mathrm{dB}$ levels $(\mathrm{F}(6,120)=27.44$; $p<0.001)$. PPI was not disrupted in $\mathrm{R}(\mathrm{AB})$ mice compared to corresponding wild-type mice $(\mathrm{F}(1,20)=0.21 ; p=0.65)$, and no significant genotype $\times \mathrm{dB}$ interaction was found $(\mathrm{F}(3,60)=0.33 ; p=0.81 ;$ Figure 2b). PPI levels were significantly different across dB levels $(F(3,60)=53.38$; $p<0.001)$. 

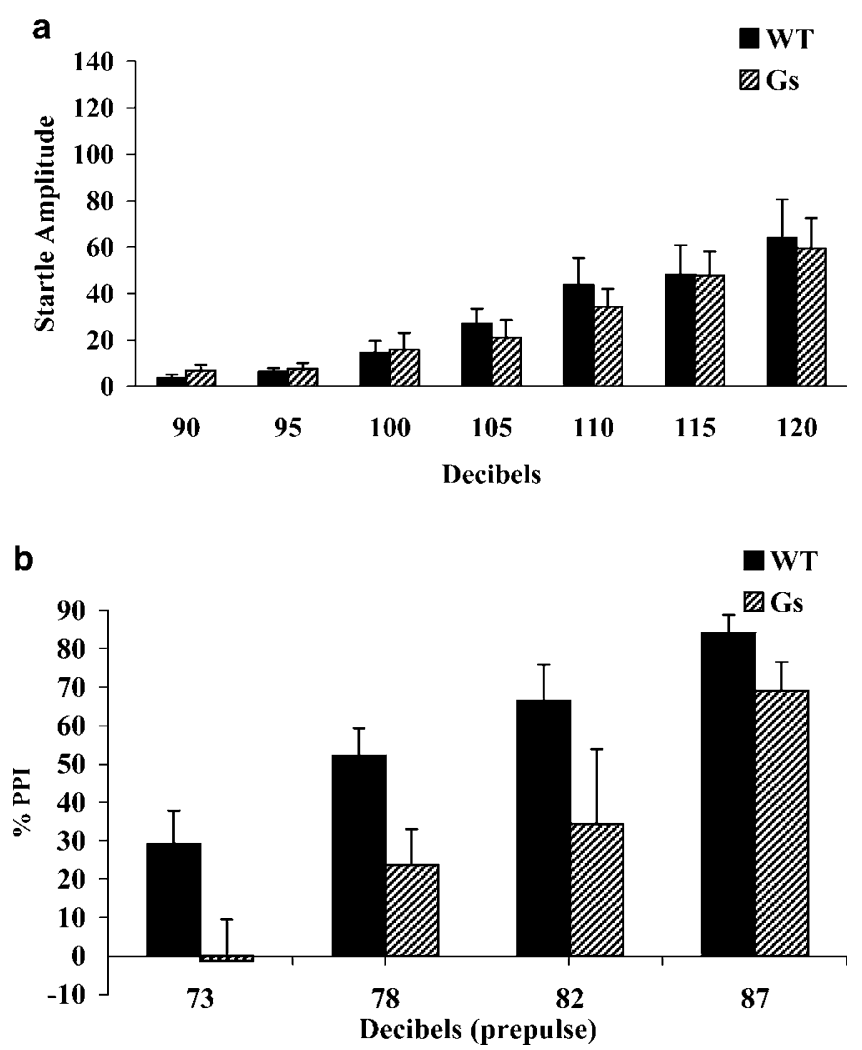

Figure I Prepulse inhibition and startle response of $\mathrm{G}_{s} \alpha^{*}$ transgenic mice measured with protocol I. (a) $\mathrm{G}_{s} \alpha^{*}$ (Gs) and wild-type (WT) littermates did not differ in overall startle response. (b) Mice were tested at four prepulse intensities with a $120 \mathrm{~dB}$ startle pulse and $65 \mathrm{~dB}$ white noise background. Overexpression of $G_{s} \alpha^{*}$ transgene was associated with significant PPI deficits relative to WT mice.

$\mathrm{G}_{\mathrm{s}} \alpha^{*}$ Transgenic Mice, but Not R(AB) Transgenic Mice, Exhibit PPI Deficits (Protocol 2)

Protocol 2 tested PPI with a $100 \mathrm{~ms}$ interstimulus interval between the $20 \mathrm{~ms}$ prepulse and the $40 \mathrm{~ms}$ startle stimulus. $\mathrm{G}_{s} \alpha^{*}(n=18)$ and wild-type control $(n=18)$ mice were analyzed for startle reactivity at seven different sound intensities, and tested for PPI at three different prepulse intensities, using a startle intensity of $120 \mathrm{~dB}$ (Figure 3). In addition, the subjects were given 'no stimulus' trials to measure the baseline movement and make the trial sequence less predictable. As found using protocol 1, the overall startle response did not differ between $G_{s} \alpha^{*}$ and wild-type mice $(\mathrm{F}(1,34)=0.017 ; p=0.90$; Figure $3 \mathrm{a})$. No significant genotype $\times \mathrm{dB}$ interaction was observed $(\mathrm{F}(6,204)=0.74 ; p=0.62)$, nor were differences in baseline movement found between $\mathrm{G}_{\mathrm{s}} \alpha^{*}$ and wild-type mice (no stimulus trials; $t(34)=0.42 ; p=0.673$ ). Startle response was significantly different across $\mathrm{dB}$ levels $(\mathrm{F}(6,204)=65.38$; $p<0.001)$. Prepulse inhibition was reduced in $\mathrm{G}_{s} \alpha^{\star}$ mice $(\mathrm{F}(1,34)=4.74 ; p<0.05 ;$ Figure $3 \mathrm{~b})$, as observed using protocol 1. In addition, PPI levels were significantly different across $d B$ levels $(F(2,68)=23.91 ; p<0.001)$, but no significant genotype $\times \mathrm{dB}$ interaction was found $(\mathrm{F}(2,68)=1.39 ; p=0.26)$.

$\mathrm{R}(\mathrm{AB})$ transgenic mice $(n=11)$ and wild-type littermate mice $(n=11)$ were also tested in protocol 2 (Figure 4$)$. The
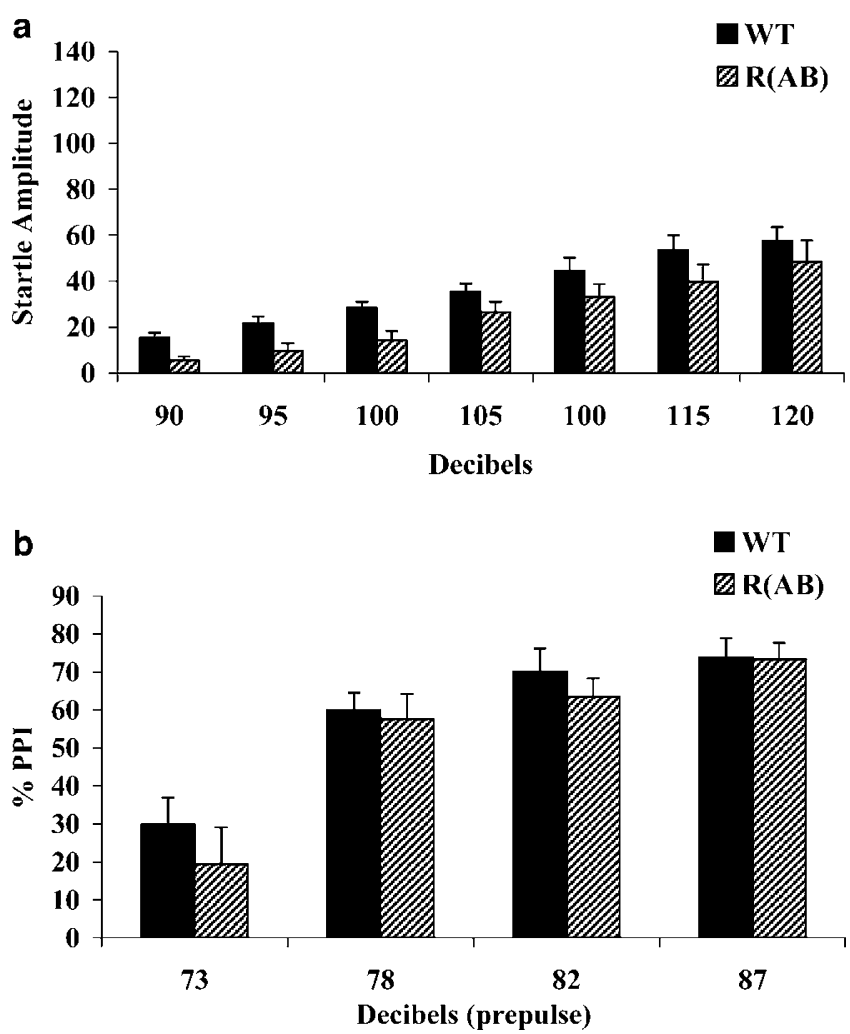

Figure 2 Prepulse inhibition and startle response of $R(A B)$ transgenic mice measured with protocol I. (a) Average startle response to startle stimuli ranging in decibel levels from $90-120 \mathrm{~dB}$ was recorded in $R(A B)$ transgenic mice and corresponding wild-type mice (WT). The $R(A B)$ transgenic mice did not have a deficit in acoustic startle response. (b) The $R(A B)$ transgenic mice and corresponding wild-type mice were tested for prepulse inhibition of startle response to a $120 \mathrm{~dB}$ startle stimulus across a range of prepulse intensities $(73-87 \mathrm{~dB}$ ) with $65 \mathrm{~dB}$ background white noise. Expression of the $R(A B)$ transgene did not alter PPI.

average startle response of $\mathrm{R}(\mathrm{AB})$ transgenic mice was not significantly different from wild-type mice $(\mathrm{F}(1,20)=1.19$; $p=0.29)$; no significant genotype $\times \mathrm{dB}$ interaction effect was found $(\mathrm{F}(6,120)=0.67 ; p=0.68)$, nor were there differences in baseline movement (no stimulus trials; $t(20)=0.28 ; p=0.78)$. Startle response was significantly different across $\mathrm{dB}$ levels $(\mathrm{F}(6,120)=20.69 ; \quad p<0.001$; Figure 4a). For PPI, no main effect of genotype was found $(\mathrm{F}(1,20)=0.75 ; p=0.40)$, but a significant genotype $\times \mathrm{dB}$ interaction was found $(\mathrm{F}(2,40)=3.45 ; p<0.05$; Figure $4 \mathrm{~b})$. The $\mathrm{R}(\mathrm{AB})$ transgenic mice had greater PPI at the $69 \mathrm{~dB}$ prepulse level $(p<0.05$; Tukey corrected post hoc comparison). PPI levels were also significantly different across $\mathrm{dB}$ levels $(\mathrm{F}(2,40)=41.79 ; p<0.001)$.

\section{DISCUSSION}

The endophenotypes of schizophrenia that have been studied in animals include alterations in sensorimotor gating, latent inhibition, attention, social behavior, and cognition (Baruch et al, 1988; Dulawa et al, 1997; Feldon and Weiner, 1991; Hoffman and Donovan, 1994; Kline et al, 1998; Martinez and Geyer, 1997; Mohn et al, 1999; Solomon et al, 1981; Swerdlow and Geyer, 1998; Weiner et al, 1996). Prepulse inhibition of the startle response is a form of 


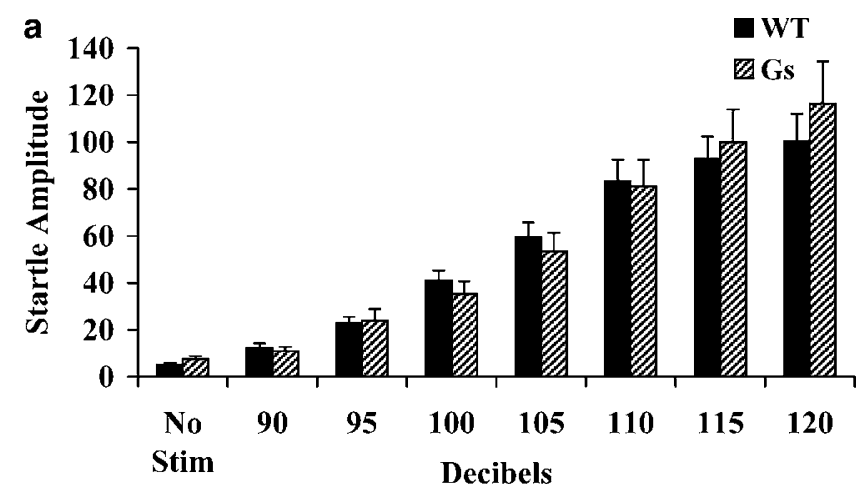

b

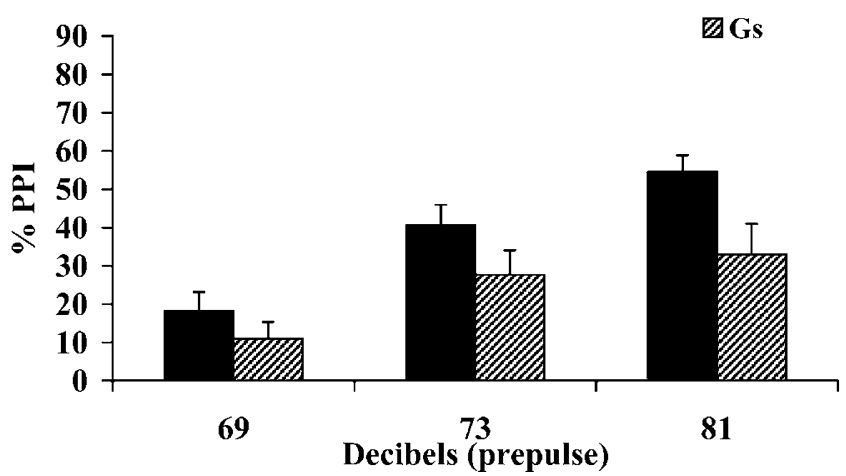

Figure 3 Prepulse inhibition and startle response of $\mathrm{G}_{\mathrm{s}} \alpha^{*}$ transgenic mice measured with protocol 2. (a) $G_{s} \alpha^{*}$ (Gs) and wild-type (WT) littermates did not differ in overall startle response. (b) Significant overall deficits in PPI were observed in $\mathrm{G}_{\mathrm{s}} \alpha^{*}$ mice tested at three prepulse intensities, with a $120 \mathrm{~dB}$ startle pulse and $65 \mathrm{~dB}$ white noise background.

sensorimotor gating that has been studied intensely, because it can easily be measured in both humans and laboratory animals, and because patients with schizophrenia, Huntington's disease, obsessive compulsive disorder, Tourette's syndrome, or attention deficit disorder show reliable deficits in PPI (Geyer and Braff, 1987; Koch, 1999; Swerdlow and Geyer, 1998). The reduced PPI found in patients with schizophrenia may reflect a loss of sensorimotor gating that could serve as the basis for the sensory flooding and cognitive impairments that these patients experience. The development of animal models has been critical not only for understanding the neurological basis of psychiatric diseases, but also for the development of novel therapeutic strategies. The goal of these studies was to examine the relationship between PPI deficits and alterations of G-protein-mediated cAMP/PKA intracellular signaling, using mice that have elevated levels of $\mathrm{G}_{\mathrm{s}}$ signaling and cAMP (Abel et al, 1997a; Wand et al, 2001), and mice that have reduced PKA activity (Abel et al, 1997b). Elevated levels of $G_{s}$ signaling were associated with deficits in PPI. The $G_{s} \alpha^{*}$ transgenic mice showed deficits in PPI in two different protocols that were based on protocols reported to successfully establish PPI in mice (Tarantino et al, 2000; Ralph et al, 1999). This suggests that the PPI deficits in the $\mathrm{G}_{s} \alpha^{*}$ transgenic mice are not dependent on the PPI protocol used. Although we have only analyzed one line of $\mathrm{G}_{s} \alpha^{*}$ transgenic mice in the studies reported here, our recent studies have revealed PPI deficits in other transgenic lines overexpressing $\mathrm{G}_{s} \alpha$ (Kelly et al, 2003).
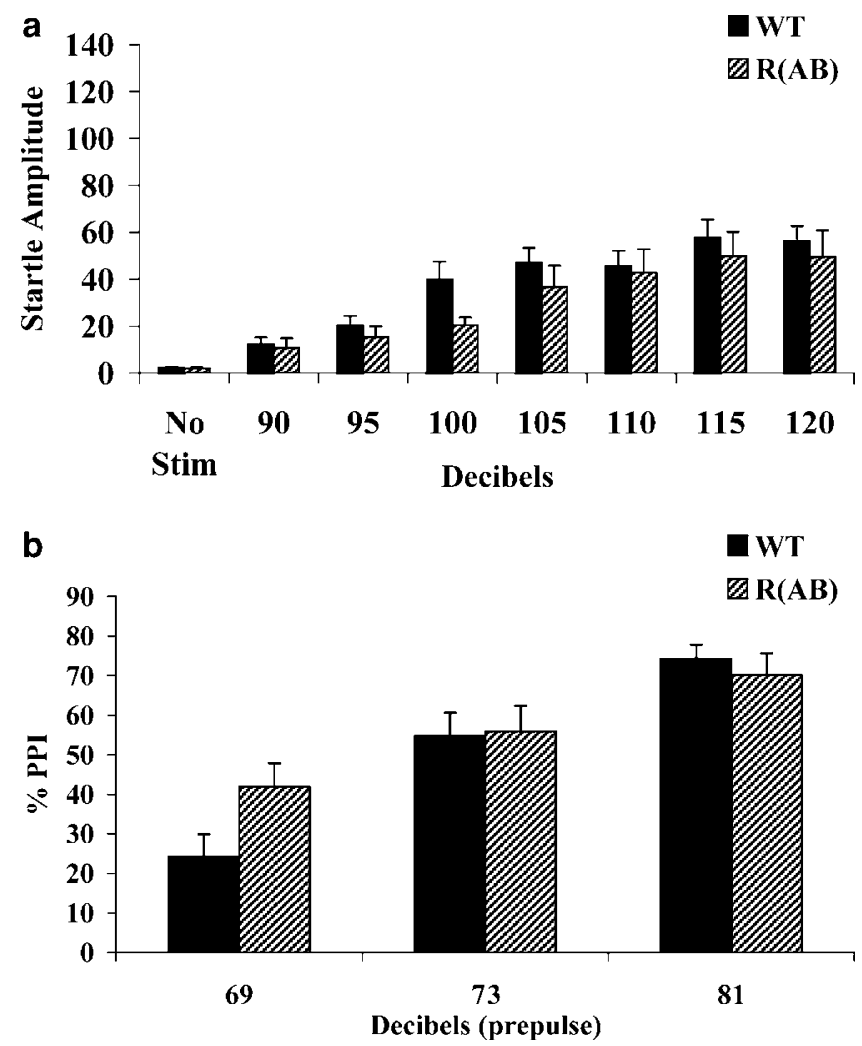

Figure 4 Prepulse inhibition and startle response of $R(A B)$ transgenic mice measured with protocol 2. (a) The $R(A B)$ transgenic mice did not have a deficit in acoustic startle response. (b) For PPI, an interaction between genotype and prepulse $d B$ level existed. The $R(A B)$ transgenic mice had a greater level of PPI compared to wild-type mice at the $69 \mathrm{~dB}$ prepulse level.

Cognitive impairments represent another important class of endophenotypes typical of schizophrenia. Specific abnormalities are present in attention, memory, and executive functions (Rund and Borg, 1999). Studies by Saykin et al $(1991,1994)$ have demonstrated a selective deficit in learning and memory compared to other cognitive areas in a sample of unmedicated patients. In these studies, verbal memory and learning deficits accounted for most of the variance between patients and controls, supporting an important role for the left-temporal hippocampal system in schizophrenia. Interestingly, although many studies of animal models have focused on sensory and sensorimotor gating, few animal studies have focused on hippocampusdependent forms of learning and memory as potential endophenotypes of schizophrenia. It may be that an appropriate animal model of this complex disease would exhibit deficits in both learning as well as sensorimotor gating. Thus, the $\mathrm{G}_{s} \alpha^{*}$ mice are of particular interest because the changes in learning and memory (Abel et al, 1997a), sensorimotor gating, and G-protein function noted in these transgenic mice may model changes seen in schizophrenia. Experiments are underway to determine if antipsychotics ameliorate PPI deficits in the $\mathrm{G}_{s} \alpha^{*}$ transgenic mice (Kelly et al, 2003).

$\mathrm{R}(\mathrm{AB})$ transgenic mice also have disrupted hippocampusdependent learning and synaptic plasticity (Abel et al, 1997b; Woo et al, 2002, 2000). Interestingly, the R(AB) mice did not exhibit deficits in PPI. This demonstrates that 
alterations in hippocampal cAMP/PKA signaling and associated deficits in hippocampus-dependent learning do not predict deficits in PPI. These data suggest that PKA in neurons within the forebrain (cortex, hippocampus, striatum and amygdala) does not play an essential or necessary role for startle and PPI. This is in contrast to our observations of deficits in sensorimotor gating in $G_{s} \alpha^{*}$ transgenic mice in which the cAMP/PKA pathway has been constitutively activated. Combined, these experiments support the idea (discussed below) that the cAMP/PKA signaling pathway serves to modulate PPI, perhaps by acting in brain regions such as the hippocampus and or nucleus accumbens that modify the startle circuitry (Koch, 1999). However, it is important to note that these transgenes are expressed in subpopulations of neurons in specific brain regions. Thus, our results for PPI do not exclude the involvement of PKA in cell types or brain regions not expressing the transgene. Additionally, the lack of deficit in the $R(A B)$ mice could be due to compensatory changes associated with expression of the $R(A B)$ transgene that mask the role of PKA in PPI.

Schizophrenia-associated deficits in multiple neurotransmitter receptor subtypes may be related to common underlying mechanisms, such as changes in shared intracellular signaling pathways. Many of the neurotransmitters implicated in schizophrenia utilize G-protein coupled receptors, raising the possibility that the misregulation of G-protein signaling plays a role in the molecular changes underlying the pathophysiology of this disorder. This idea is supported by recent microarray studies that observed alterations in RGS4 in patients with schizophrenia (Chowdari et al, 2002; Mirnics et al, 2001). Our data demonstrate that $\mathrm{G}_{\mathrm{s}} \alpha^{*}$ transgenic mice, which overexpress $\mathrm{G}_{s} \alpha^{*}$, exhibit a deficit in PPI without changes in the startle response itself. These results strongly imply that overactivation of $G_{s}$ signaling can cause sensorimotor gating abnormalities.

The mechanism by which overexpression of $\mathrm{G}_{\mathrm{s}} \alpha^{*}$ disrupts PPI is not clear, but it could relate to the modulation of neurotransmitter systems such as the dopaminergic system. Both clinical and animal studies of PPI have defined a role for dopamine in this form of startle plasticity. Indirect dopamine agonists, such as amphetamine, and direct dopamine agonists, such as apomorphine, disrupt PPI in rats (Mansbach et al, 1988) and mice (Ralph et al, 1999). Importantly, these disruptions in PPI are reversed by typical and atypical antipsychotics, and the ability of antipsychotics to restore PPI strongly correlates with their clinical potency (Swerdlow et al, 1994). Numerous studies have demonstrated dopamine agonist-induced disruption of PPI, and this effect appears to be dependent on the $D_{2}$ receptor (Ralph et al, 1999). However, increasing evidence demonstrates a role of the $D_{1}$ receptor in PPI. In mice, the $D_{1}$ agonist SKF82958 significantly reduced PPI and the $D_{1}$ antagonist $\mathrm{SCH} 23390$ blocked the mixed $\mathrm{D}_{1} / \mathrm{D}_{2}$ agonist apomorphine disruption of PPI (Ralph-Williams et al, 2003). Thus, the roles of $D_{1}$ and $D_{2}$ receptor subtypes in disruption of PPI still need to be resolved. In humans, the $\mathrm{D}_{2}$ agonist pergolide failed to disrupt PPI (Braff et al, 2001; Swerdlow et al, 2002). The effects of direct $D_{1}$ agonists on PPI in humans have not been reported. Because the $D_{1}$ receptor is coupled to $G_{s}$, overexpression of $G_{s} \alpha^{*}$ may produce effects on PPI similar to $D_{1}$ agonists. In the $G_{s} \alpha^{*}$ transgenic mice, overexpression of the $G_{s} \alpha$ transgene is limited to forebrain areas that include the hippocampus, nucleus accumbens, and prefrontal cortex, suggesting that the modulation of PPI is due to altered CAMP signaling in one of these brain regions.

Overexpression of $\mathrm{G}_{\mathrm{s}} \alpha^{*}$ could increase neural activity that drives dopamine release in brain areas involved in PPI. The nucleus accumbens is a subcortical integrative center that connects forebrain structures such as the hippocampus, prefrontal cortex, and amygdala to circuits that mediate PPI. The nucleus accumbens receives a dense dopaminergic projection from the ventral tegmental area, and excessive dopamine receptor stimulation within the nucleus accumbens reduces PPI (reviewed in Koch, 1999; Swerdlow and Geyer, 1998). Dopamine release in the nucleus accumbens is controlled in part by glutamatergic afferents from the limbic system. Glutamatergic neurons from the hippocampus and medial prefrontal cortex project to the nucleus accumbens. Hippocampal fibers enhance dopamine release from ventral neurons in the shell region of the nucleus accumbens via a direct presynaptic mechanism mediated by glutamate, and PPI is disrupted after stimulation of the ventral hippocampus. The medial prefrontal cortex projects to the core region of the nucleus accumbens, where these projections enhance dopamine release. Since a disturbance in the interaction between glutamate and dopamine is thought to play a role in the pathophysiology of schizophrenia, the nucleus accumbens is a prominent structure in models of sensory gating deficits in patients.

Because startle was not altered in the transgenic mice, this suggests that the disruption of PPI in $\mathrm{G}_{\mathrm{s}} \alpha^{*}$ transgenic mice was not likely to be due to changes in the brainstem, but more likely to be due to changes in forebrain areas (see Koch, 1999). The hippocampal-accumbal projection appears to be a crucial regulator of dopamine release within the accumbens. Previous electrophysiological experiments found enhanced basal synaptic transmission within the hippocampus of the $\mathrm{G}_{\mathrm{s}} \alpha^{*}$ transgenic mice (Abel et al, 1997a). If synaptic transmission in the hippocampalaccumbal pathway is also enhanced, then transgenic mice would be expected to have elevated levels of dopamine within the accumbens, thus resulting in a deficit in PPI. Although the dopamine system, in particular, is a central player in the modulation of PPI, other neurotransmitter systems, including serotonin, noradrenaline, and glutamate, also play a role in PPI. Thus, it is possible that disrupted PPI in the $G_{s} \alpha^{*}$ transgenic mice is a result of alterations to one or more neurotransmitter systems. Future experiments will be directed at identifying the neurotransmitter systems and brain regions involved.

The $\mathrm{G}_{\mathrm{s}} \alpha^{*}$ transgenic mice may provide an interesting animal model of schizophrenia. These mice have altered Gprotein signaling that models the imbalance of G-protein signaling observed in schizophrenia (Nishino et al, 1993). In addition, the $G_{s} \alpha^{*}$ transgenic mice have deficits in both PPI and hippocampus-dependent spatial learning, similar to deficits associated with schizophrenia (Geyer and Braff, 1987; Rund and Borg, 1999; Swerdlow and Geyer, 1998). The study of altered G-protein signaling as a potential underlying cause of schizophrenia has potentially important clinical and pharmacological ramifications, and it will be 
interesting to examine the effects of antipsychotics on the PPI deficits in $\mathrm{G}_{\mathrm{s}} \alpha^{*}$ transgenic mice.

\section{ACKNOWLEDGEMENTS}

We would like to thank Jennifer Davis for continued discussions about this work and David Rapoport for assistance with genotyping. This work was supported by P50 MH 6404501, Project 3 to TA (R Gur, Conte Center P.I.), NIMH K08 MH067091 to SJK, along with NIMH RO1 MH60244 and NIA RO1 AG18199, and by grants from the Whitehall Foundation, the University of Pennsylvania Research Foundation, and a Young Investigator Award from the Mental Retardation and Development Disabilities Research Center at Children's Hospital of Philadelphia (HD26979) to TA. TA is a John Merck Scholar and a David and Lucile Packard Foundation Fellow. MPK is supported by NIMH T32 MH019112 (R. Gur, P.I.).

\section{REFERENCES}

Abel T, Bourtchouladze R, Patterson SL, Barad M, Winder V, Deuel TA et al (1997a). Transgenic mice expressing a constitutively active form of GalphaS exhibit learning deficits and enhanced synaptic transmission. Soc Neurosci Abstr 23: 1177.

Abel T, Nguyen PV, Barad M, Deuel TA, Kandel ER, Bourtchouladze R (1997b). Genetic demonstration of a role for PKA in the late phase of LTP and in hippocampus-based long-term memory. Cell 88: 615-626.

Adler LE, Pachtman E, Franks RD, Pecevich M, Waldo MC, Freedman R (1982). Neurophysiological evidence for a defect in neuronal mechanisms involved in sensory gating in schizophrenia. Biol Psychiatry 17: 639-654.

Andreasen NC, Black DW (1995). Introductory Textbook of Psychiatry. American Psychiatric Press: Washington, DC.

Avissar S, Roitman G, Schreiber G (2001). Differential effects of the antipsychotics haloperidol and clozapine on $G$ protein measures in mononuclear leukocytes of patients with schizophrenia. Cell Mol Neurobiol 21: 799-811.

Baruch I, Hemsley DR, Gray JA (1988). Differential performance of acute and chronic schizophrenics in a latent inhibition task. J Nerv Ment Dis 176: 598-606.

Bassett AS, Chow EW, Weksberg R (2000). Chromosomal abnormalities and schizophrenia. Am J Med Genet 97: 45-51.

Boutros NN, Zouridakis G, Overall J (1991). Replication and extension of P50 findings in schizophrenia. Clin Electroencephalogr 22: 40-45.

Braff DL, Geyer MA, Swerdlow NR (2001). Human studies of prepulse inhibition of startle: normal subjects, patient groups, and pharmacological studies. Psychopharmacology (Berl) 156: 234-258.

Bucan M, Abel T (2002). The mouse: genetics meets behaviour. Nat Rev Genet 3: 114-123.

Cadenhead KS, Swerdlow NR, Shafer KM, Diaz M, Braff DL (2000). Modulation of the startle response and startle laterality in relatives of schizophrenic patients and in subjects with schizotypal personality disorder: evidence of inhibitory deficits. Am J Psychiatry 157: 1660-1668.

Chowdari KV, Mirnics K, Semwal P, Wood J, Lawrence E, Bhatia T et al (2002). Association and linkage analyses of RGS4 polymorphisms in schizophrenia. Hum Mol Genet 11: 1373-1380.

Clegg C, Correll LA, Cadd GG, McKnight GS (1987). Inhibition of intracellular cAMP-dependent protein kinase using mutant genes of the regulatory type I subunit. $J$ Biol Chem 262: 13111-13119.
Clementz BA, Geyer MA, Braff DL (1997). P50 suppression among schizophrenia and normal comparison subjects: a methodological analysis. Biol Psychiatry 41: 1035-1044.

Connolly PM, Maxwell CR, Kanes SJ, Abel T, Liang Y, Tokarczyk J et al (2003). Inhibition of auditory evoked potentials and prepulse inhibition of startle in DBA/2J and DBA/2 Hsd inbred mouse substrains. Brain Research, (in press).

Dulawa SC, Hen R, Scearce-Levie K, Geyer MA (1997). Serotonin1B receptor modulation of startle reactivity, habituation, and prepulse inhibition in wild-type and serotonin1B knockout mice. Psychopharmacology (Berl) 132: 125-134.

Dulawa SC, Hen R, Scearce-Levie K, Geyer MA (1998). 5-HT1B receptor modulation of prepulse inhibition: recent findings in wild-type and 5-HT1B knockout mice. Ann NY Acad Sci 861: 79-84.

Erwin RJ, Mawhinney-Hee M, Gur RC, Gur RE (1991). Midlatency auditory evoked responses in schizophrenia. Biol Psychiatry 30: 430-442.

Feldon J, Weiner I (1991). The latent inhibition model of schizophrenic attention disorder. Haloperidol and sulpiride enhance rats' ability to ignore irrelevant stimuli. Biol Psychiatry 29: 635-646.

Freedman R, Adler LE, Myles-Worsley M, Nagamoto HT, Miller C, Kisley M et al (1996). Inhibitory gating of an evoked response to repeated auditory stimuli in schizophrenic and normal subjects. Human recordings, computer simulation, and an animal model. Arch Gen Psychiatry 53: 1114-1121.

Geyer MA, Braff DL (1987). Startle habituation and sensorimotor gating in schizophrenia and related animal models. Schizophr Bull 13: 643-668.

Geyer MA, Krebs-Thomson K, Braff DL, Swerdlow NR (2001). Pharmacological studies of prepulse inhibition models of sensorimotor gating deficits in schizophrenia: a decade in review. Psychopharmacology (Berl) 156: 117-154.

Ginty DD, Glowacka D, Bader DS, Hidaka H, Wagner JA (1991a). Induction of immediate early genes by $\mathrm{Ca}^{2+}$ influx requires cAMP-dependent protein kinase in PC12 cells. J Biol Chem 266: 17454-17458.

Ginty DD, Glowacka D, DeFranco C, Wagner JA (1991b). Nerve growth factor-induced neuronal differentiation after dominant repression of both Type I and Type II cAMP-dependent protein kinase activities. J Biol Chem 266: 15325-15333.

Gould TJ, Abel T (2000). Transgenic mice that overexpress a constitutively active form of $\mathrm{G} \alpha$ s have disrupted prepulse inhibition. Soc Neurosci Abstr 26: 1538.

Hoffman DC, Donovan H (1994). D1 and D2 dopamine receptor antagonists reverse prepulse inhibition deficits in an animal model of schizophrenia. Psychopharmacology (Berl) 115: 447-453.

Holmes A, Hollon TR, Gleason TC, Liu Z, Dreiling J, Sibley DR et al (2001). Behavioral characterization of dopamine D5 receptor null mutant mice. Behav Neurosci 115: 1129-1144.

Judd LL, McAdams L, Budnick B, Braff DL (1992). Sensory gating deficits in schizophrenia: new results. Am J Psychiatry 149: 488-493.

Kelly MP, Tokarczyk J, Rapoport DA, Godfrey M, Kanes SJ, Abel T (2003). Modeling cognitive deficits of schizophrenia in mice with altered G-protein signaling. Soc Neurosci Abstr 29: 858.2.

Kline L, Decena E, Hitzemann R, McCaughran Jr J (1998). Acoustic startle, prepulse inhibition, locomotion, and latent inhibition in the neuroleptic-responsive (NR) and neurolepticnonresponsive (NNR) lines of mice. Psychopharmacology (Berl) 139: 322-331.

Koch M (1999). The neurobiology of startle. Prog Neurobiol 59: 107-128.

Mansbach RS, Geyer MA, Braff DL (1988). Dopaminergic stimulation disrupts sensorimotor gating in the rat. Psychopharmacology 94: 507-514. 
Martinez DL, Geyer MA (1997). Characterization of the disruptions of prepulse inhibition and habituation of startle induced by alpha-ethyltryptamine. Neuropsychopharmacology 16: 246-255.

Mayford M, Baranes D, Podsypanina K, Kandel ER (1996). The 3' untranslated region of CaMKII $\alpha$ in a cis-acting signal for the localization and translation of mRNA in dendrites. Proc Natl Acad Sci USA 93: 13250-13255.

Mellon PL, Clegg CL, Correll LA, McKnight GS (1989). Regulation of transcription by cyclic AMP-dependent protein kinase A. Proc Natl Acad Sci USA 86: 4887-4891.

Mirnics K, Middleton FA, Stanwood GD, Lewis DA, Levitt P (2001). Disease-specific changes in regulator of G-protein signaling 4 (RGS4) expression in schizophrenia. Mol Psychiatry 6: 293-301.

Mohn AR, Gainetdinov RR, Caron MG, Koller BH (1999). Mice with reduced NMDA receptor expression display behaviors related to schizophrenia. Cell 98: 427-436.

Nishino N, Kitamura N, Hashimoto T, Kajimoto Y, Shirai Y, Murakami $\mathrm{N}$ et al (1993). Increase in $\left[{ }^{3} \mathrm{H}\right] \mathrm{cAMP}$ binding sites and decrease in Gi alpha and Go alpha immunoreactivities in left temporal cortices from patients with schizophrenia. Brain Res 615: 41-49.

Okada F, Crow TJ, Roberts GW (1991). G proteins (Gi, Go) in the medial temporal lobe in schizophrenia: preliminary report of a neurochemical correlate of structural change. J Neural Transm Gen Sect 84: 147-153.

Okada F, Tokumitsu Y, Takahashi N, Crow TJ, Roberts GW (1994). Reduced concentrations of the alpha-subunit of GTP-binding protein Go in schizophrenic brain. J Neural Transm Gen Sect 95: 95-104.

Owen MJ (2000). Molecular genetic studies of schizophrenia. Brain Res Brain Res Rev 31: 179-186.

Peng RY, Mansbach RS, Braff DL, Geyer MA (1990). A D2 dopamine receptor agonist disrupts sensorimotor gating in rats. Implications for dopaminergic abnormalities in schizophrenia. Neuropsychopharmacology 3: 211-218.

Ralph RJ, Varty GB, Kelly MA, Wang YM, Caron MG, Rubinstein $\mathrm{M}$ et al (1999). The dopamine D2, but not D3 or D4, receptor subtype is essential for the disruption of prepulse inhibition produced by amphetamine in mice. J Neurosci 19: 4627-4633.

Ralph-Williams RJ, Lehmann-Masten V, Geyer MA (2003). Dopamine $\mathrm{d} 1$ rather than $\mathrm{d} 2$ receptor agonists disrupt prepulse inhibition of startle in mice. Neuropsychopharmacology 28: $108-118$.

Rigdon GC, Weatherspoon JK (1992). 5-Hydroxytryptamine 1a receptor agonists block prepulse inhibition of acoustic startle reflex. J Pharmacol Exp Ther 263: 486-493.

Rund BR, Borg NE (1999). Cognitive deficits and cognitive training in schizophrenic patients: a review. Acta Psychiatr Scand 100: 85-95.

Sawa A, Snyder SH (2002). Schizophrenia: diverse approaches to a complex disease. Science 296: 692-695.

Saykin AJ, Gur RC, Gur RE, Mozley PD, Mozley LH, Resnick SM et al (1991). Neuropsychological function in schizophrenia. Selective impairment in memory and learning. Arch Gen Psychiatry 48: 618-624.

Saykin AJ, Shtasel DL, Gur RE, Kester DB, Mozley LH, Stafiniak P et al (1994). Neuropsychological deficits in neuroleptic naive patients with first-episode schizophrenia. Arch Gen Psychiatry 51: 124-131.
Sipes TA, Geyer MA (1994). Multiple serotonin receptor subtypes modulate prepulse inhibition of the startle response in rats. Neuropharmacology 33: 441-448.

Sipes TA, Geyer MA (1995a). 8-OH-DPAT disruption of prepulse inhibition in rats: reversal with (+)WAY 100,135 and localization of site of action. Psychopharmacology (Berl) 117: 41-48.

Sipes TE, Geyer MA (1995b). DOI disruption of prepulse inhibition of startle in the rat is mediated by $5-\mathrm{HT}(2 \mathrm{~A})$ and not by 5-HT(2C) receptors. Behav Pharmacol 6: 839-842.

Solomon PR, Crider A, Winkelman JW, Turi A, Kamer RM, Kaplan LJ (1981). Disrupted latent inhibition in the rat with chronic amphetamine or haloperidol-induced supersensitivity: relationship to schizophrenic attention disorder. Biol Psychiatry 16: 519-537.

Stevens KE, Freedman R, Collins AC, Hall M, Leonard S, Marks MJ et al (1996). Genetic correlation of inhibitory gating of hippocampal auditory evoked response and alpha-bungarotoxin-binding nicotinic cholinergic receptors in inbred mouse strains. Neuropsychopharmacology 15: 152-162.

Swerdlow NR, Braff DL, Taaid N, Geyer MA (1994). Assessing the validity of an animal model of deficient sensorimotor gating in schizophrenic patients. Arch Gen Psychiatry 51: 139-154.

Swerdlow NR, Eastvold A, Karban B, Ploum Y, Stephany N, Geyer MA et al (2002). Dopamine agonist effects on startle and sensorimotor gating in normal male subjects: time course studies. Psychopharmacology (Berl) 161: 189-201.

Swerdlow NR, Geyer MA (1998). Using an animal model of deficient sensorimotor gating to study the pathophysiology and new treatments of schizophrenia. Schizophr Bull 24: 285-301.

Tarantino LM, Bucan M (2000). Dissection of behavior and psychiatric disorders using the mouse as a model. $\mathrm{Hum} \mathrm{Mol}$ Genet 9: 953-965.

Tarantino LM, Gould TJ, Druhan JP, Bucan M (2000). Behavior and mutagenesis screens: the importance of baseline analysis of inbred strains. Mamm Genome 11: 555-564.

Wan FJ, Taaid N, Swerdlow NR (1996). Do D1/D2 interactions regulate prepulse inhibition in rats? Neuropsychopharmacology 14: $265-274$

Wand G, Levine M, Zweifel L, Schwindinger W, Abel T (2001). The cAMP-protein kinase A signal transduction pathway modulates ethanol consumption and sedative effects of ethanol. $J$ Neurosci 21: 5297-5303.

Weickert CS, Kleinman JE (1998). The neuroanatomy and neurochemistry of schizophrenia. Psychiatr Clin North Am 21: 57-75.

Weiner I, Shadach E, Tarrasch R, Kidron R, Feldon J (1996). The latent inhibition model of schizophrenia: further validation using the atypical neuroleptic, clozapine. Biol Psychiatry 40: 834-843.

Woo NH, Abel T, Nguyen PV (2002). Genetic and pharmacological demonstration of a role for cyclic AMP-dependent protein kinase-mediated suppression of protein phosphatases in gating the expression of late LTP. Eur J Neurosci 16: 1871-1876.

Woo NH, Duffy SN, Abel T, Nguyen PV (2000). Genetic and pharmacological demonstration of differential recruitment of cAMP-dependent protein kinases by synaptic activity. J Neurophysiol 84: 2739-2745.

Yang CQ, Kitamura N, Nishino N, Shirakawa O, Nakai H (1998). Isotype-specific $\mathrm{G}$ protein abnormalities in the left superior temporal cortex and limbic structures of patients with chronic schizophrenia. Biol Psychiatry 43: 12-19. 